\title{
ANALISIS RENTABILITAS BERBASIS LAPORAN KEUANGAN BRI SYARIAH TAHUN 2013-2015
}

\author{
Abdul Haris Romdhoni \\ STIE-AAS \\ Email: harisromdhoni27@yahoo.com
}

\begin{abstract}
This study aims to examine the profitability of financial ratios. Profitability became quite urgent, because the profitability is the ability of a company to generate profit with the capabilities of the BRI Syariah. It was often a problem in some companies or banks. Profitability for the Year 2013-2015 BRI Syariah good enough for the performance of this study dipenghujung BRI Syariah able to improve its financial performance either ROA, ROE, net income margin and operating expenses.
\end{abstract}

Keywords: profitability, financial ratios and financial performance.

\section{PENDAHULUAN}

Laba dan risiko selalu tidak dapat lepas dari suatu bisnis. Sejak tahun 1990an lembaga keuangan baik bank maupun non-bank berkembang pesat. Lembaga keuangan tersebut, terutama bank, juga memiliki berbagai variasi dalam berbagai prinsip implementasi. Hal itu dapat dilihat baik bank syariah maupun bank konvensional.

Bank Indonesia (BI) dan Otoritas Jasa Keuangan (OJK) bertanggung jawab berperan dalam pembinaan dan pegawasan operasionalisasi bank. Oleh sebab itu BI dan OJK meminta setiap bulan maupun tahun untuk melaporkan kondisi keuangannya. Laporan keuangan dapat dijadikan sebagai gambaran kondisi perbankan secara mikro yang kemudian digunakan sebagai kebijakan dalam perekonomian. Dengan laporan keuangan pula dapat dilihat kinerja atau rasio keuangan dari bank tersebut. Hal itu tidak lepas pula karena bertujuan untuk mendapatkan laba atau meningkatkan harga saham.

Faktor fundamental selalu dijadikan acuan investor dalam membuat keputusan investasi di pasar modal. Analisis faktor fundamental didasarkan pada laporan keuangan perusahaan yang dapat dianalisis melalui analisis rasiorasio keuangan dan ukuran-ukuran lainnya seperti cash flow untuk mengukur kinerja keuangan perusahaan. Rasio keuangan dikelompokkan dalam lima jenis yaitu : (1) rasio likuiditas, yaitu rasio yang menyatakan kemampuan perusahaan untuk memenuhi kewajibannya dalam jangka pendek; (2) rasio aktivitas, menyatakan kemampuan perusahaan dalam memanfaatkan harta yang dimikinya; (3) rasio profitabilitas, menunjukkan kemampuan dari perusahaan dalam menghasilkan keuntungan; (4) rasio solvabilitas 
(leverage), menunjukkan kemampuan perusahaan dalam memenuhi kewajiban jangka panjang, dan (5) rasio pasar, menunjukkan informasi penting perusahaan dan diungkapkan dalam basis per saham.

Industri Perbankan merupakan industri yang syarat dengan risiko, terutama karena melibatkan pengelolaan uang masyarakat dan diputar dalam bentuk berbagai investasi, seperti pemberian kredit, pembelian surat-surat berharga dan penanaman dana lainnya (Ghozali, 2007).

$$
\text { Rasio sendiri adalah }
$$

menggambarkan suatu hubungan atau perimbangan (mathematical relationship) antara suatu jumlah tertentu dengan jumlah yang lain (Munawir, 2000:54). Rasio sebenarnya adalah alat yang dinyatakan dalam aritmathical terms yang dapat digunakan untuk menjelaskan hubungan antara dua macam data finansial (Bambang Riyanto, 2001:329). Rasio keuangan merupakan suatu informasi yang menggambarkan hubungan antara berbagai macam akun (accounts) dari laporan keuangan yang mencerminkan keadaan keuangan serta hasil operasional perusahaan. Sedangkan studi yang berfungsi untuk mempelajari rasio keuangan tersebut disebut analisa rasio keuangan (financial ratios analysis)..

Dari rasio keuangan dapat digunakan untuk mengetahui tingkat kesehatan keuangan suatu bank diperlukan alat-alat analisa finansiil. Diantara alat finansiil yang digunakan adalah analisa rasio. Umumnya analisa rasio yang digunakan untuk mengukur kesehatan finansiil suatu perusahaan adalah analisa rasio rentabilitas, likuiditas, solvabilitas ini merupakan indikator utamanya sedangkan indikator tambahan terdiri dari profit margin, rasio operasi, dan produktivitas tenaga kerja. Untuk mempertahankan dan meningkatkan kepercayaan masyarakat, maka manajemen bank harus memperhatikan kinerja usahanya. Salah satu penilaian terhadap kinerja perbankan adalah dengan melihat pada tingkat rentabilitasnya (Prasetyo, 2009).

Rentabilitas perbankan salah satunya adalah menggambarkan sejauh mana keberhasilan bank itu menggunakan dana yang diinvestasikannya. Untuk mempertahankan suatu tingkat rentabilitas yang layak, bank harus memperoleh penghasilan yang dapat menutupi biaya, dan bank tersebut harus berusaha terus mempertahankan tingkat pendapatan tertentu dengan memperhitungkan faktor risiko yang dihadapi (Hermawan, 2009).Berdasar pemikiran diatas dan mengingat pentingnya kinerja keuangan maka dalam penelitian ini akan meneliti tentang Analisis Rentabilitas Berbasis Laporan Keuangan BRI Syariah Tahun 2013-2015

\section{Rumusan Masalah}

Permasalahan dalam penelitian ini dapat dirumuskan sebagai berikut :

1. Bagaimanakah perkembangan kinerja keuangan (rentabilitas) BRI Syariah Tahun 2013-2015 ?.

2. Apakah kinerja keuangan (rentabilitas) BRI Syariah Tahun 2013-2015 menunjukkan pergerakan yang positif atau negatif ?. 


\section{Tujuan Penelitian}

1. Untuk mengetahui perkembangan kinerja keuangan (rentabilitas) BRI Syariah Tahun 2013-2015.

2. Untuk mengetahui kinerja keuangan (rentabilitas) BRI Syariah Tahun 2013-2015 menunjukkan pergerakan yang positif atau negatif.

\section{LANDASAN TEORI}

\section{a. Pengertian Bank}

Di Indonesia telah beroperasi dua sistem perbankan yaitu perbankan konvensional dan perbankan syariah. Perbankan syariah operasionalisasinya relatif baru terhitung sejak tahun 1992 dengan didirikannya Bank Muamalat Indonesia. Sementara perbankan konvensional sudah sejak lama beroperasi.

Dahlan

mengemukakan bank dapat didefinisikan sebagai badan usaha yang kegiatan utamanya adalah menerima simpanan dari masyarakat dan atau dari pihak lainnya, kemudian mengalokasikan kembali untuk memperoleh keuntungan serta menyediakan jasa-jasa dalam lalulintas pembayaran.

Menurut Undang-Undang No. 21 tahun 2008 tentang Perbankan Syariah pada pasal 1, dijelaskan bahwa perbankan syariah adalah: "segala sesuatu yang menyangkut tentang Bank Syariah dan Unit Usaha Syariah, mencakup kelembagaan, kegiatan usaha, serta cara dan proses dalam melaksanakan kegiatan usahanya". Sedangkan pengertian bank syariah : adalah bank yang menjalankan usahanya berdasarkan prinsip syariah dan menurut jenisnya terdiri atas Bank Umum Syariah dan Bank Pembiayaan Rakyat Syariah". Secara prinsip perbedaan antara bank konvensional dengan bank syariah dapat dilihat dalam tabel berikut

Tabel Perbedaan Bank Konvensional dengan Bank Syariah

\begin{tabular}{|c|c|}
\hline Bank Syari'ah & Bank Kon \\
\hline $\begin{array}{l}\text { a. Berdasarkan prinsip investasibagi hasil } \\
\text { b. Menggunakan prinsip jual-beli } \\
\text { c. Hubungan dengan nasabah dalam } \\
\text { bentukhubungan kemitraan } \\
\text { d. Melakukan investasi-investasiyang } \\
\text { halal saja } \\
\text { e. Setiap produk dan jasa yangdiberikan } \\
\text { sesuai dengan fatwaDewan Syari'ah } \\
\text { f. Dilarangnya gharar dan maisir }\end{array}$ & $\begin{array}{l}\text { a. Berdasarkan tujuan membungakan uang } \\
\text { b. Menggunakan prinsip pinjammeminjam } \\
\text { uang. } \\
\text { c. Hubungan dengan nasabah dalam bentuk } \\
\text { hubungan kreditur-debitur } \\
\text { d. Investasi yang halal maupun yang haram } \\
\text { e. Tidak mengenal Dewan sejenis itu. } \\
\text { f. Terkadang terlibat dalam speculative } \\
\text { FOREX dealing }\end{array}$ \\
\hline
\end{tabular}


g. Menciptakan keserasian diantara keduanya.

h. Tidak memberikan dana secara tunai tetapi memberikan barang yang dibutuhkan (finance thegoods and services)

i. Bagi hasil menyeimbangkan sisipasiva dan aktiva. g. Berkontribusi dalam terjadinya kesenjangan antara sektor riel dengan sektor moneter.

h. Memberikan peluang yang sangat besar untuk sight streaming (penyalahgunaan dana pinjaman)

i. Rentan terhadap negative spread

Sumber: Antonio (2001)

Di samping itu terdapat perbedaan dalam prinsip antara bunga dan bagi hasil. Keterangan lebih lanjut dapat dilihat dalam tabel berikut :

Tabel Perbedaan Sistem Bunga dengan Bagi Hasil

\begin{tabular}{|c|c|}
\hline Bunga & Bagi hasil \\
\hline $\begin{array}{l}\text { 1. Penentuan bunga di buat berdasarkan } \\
\text { perjanjian dengan asumsi harus selalu } \\
\text { untung }\end{array}$ & $\begin{array}{l}\text { 1. Penentuan nisbah bagi hasil dibuat } \\
\text { berdasarkan keuntungan bank atas } \\
\text { asas keadilan }\end{array}$ \\
\hline $\begin{array}{l}\text { 2. Besarnya presentase tergantung } \\
\text { besarnya modal yang di pinjam }\end{array}$ & $\begin{array}{l}\text { 2. } \begin{array}{l}\text { Besarnya } \\
\text { berdasarkan }\end{array} \text { pada }^{\text {pagio }} \text { jumlah }\end{array}$ \\
\hline $\begin{array}{l}\text { 3. Pembayaran bunga tetap tidak } \\
\text { tergantung keuntungan bank }\end{array}$ & $\begin{array}{l}\text { keuntungan yang diperoleh bank } \\
\text { 3. Jumlah pembagian laba meningkat } \\
\text { sesuai dengan keuntungan bank }\end{array}$ \\
\hline
\end{tabular}

Sumber : Iriyadi dan Oktafiyanthi, $2007: 19-22$.

\section{b. Laporan Keuangan}

Menurut Ghozali dan Chariri (2003) laporan keuangan merupakan salah satu sumber data untuk mengukur kinerja perusahaan. Laporan keuangan merupakan bagian dari proses pelaporan keuangan yang bertujuan untuk menyediakan informasi tentang posisi keuangan, kinerja, dan arus kas perusahaan yang bermanfaat bagi sebagian besar kalangan penggunaan laporan keuangan dalam rangka pembuatan keputusan-keputusan ekonomi serta menunjukkan pertanggung jawaban manajemen atas penggunaan sumber-sumber daya yang dipercayakan pada mereka. Laporan keuangan akan dibutuhkan dan berguna untuk berbagai pihak yang membutuhkannya, baik dari internal maupun eksternal. Sementara Baridwan (2004:17) mendefinisikan laporan keuangan merupakan ringkasan dari suatu proses pencatatan, merupakan suatu ringkasan dari taransaksitransaksi keuangan yang terjadi selama tahun buku yang bersangkutan.

\section{c. Analisis Laporan Keuangan}


Analisis laporan keuangan (financial statement analysis) adalah aplikasi dari alat dan teknik analitis untuk laporan keuangan bertujuan umum dan data-data yang berkaitan untuk menghasilkan estimasi dan kesimpulan yang bermanfaat dalam analisis bisnis. Analisis laporan keuangan mengurangi ketergantungan pada firasat, tebakan, dan intuisi dalam pengambilan keputusan. Analisis ini mengurangi ketidakpastian analisis bisnis. Analisis ini tidak mengurangi perlunya penilaian ahli, namun menyediakan dasar yang sistematis dan efektif untuk analisis bisnis (Wild et al., 2008:34).

Dengan analisis laporan keuangan akan membantu sejauh mana kondisi keuangan suatu bank mengalami perkembangan. Munawir (2010:35) menambahkan analisis laporan keuangan adalah analisis laporan keuangan yang terdiri dari penelaahan atau mempelajari daripada hubungan dan tendensi atau kecenderungan (trend) untuk menentukan posisi keuangan dan hasil operasi serta perkembangan perusahaan yang bersangkutan. Dwi Prastowo dan Rifka Juliaty menambahkan, laporan keuangan disusun dengan tujuan untuk menyediakan informasi yang menyangkut posisi keuangan, kinerja dan perubahan posisi keuangan suatu perusahaan yang bermanfaat bagi sejumlah besar pemakai dalam pengambilan keputusan ekonomi.

Menurut Sutrisno (2008: 9), "Laporan Keuangan merupakan hasil dari proses akuntansi yang meliputi dua laporan utama yakni 1.Neraca dan (2) Laporan Laba Rugi. Setiap perusahaan mempunyai laporan keuangan yang bertujuan menyediakan informasi yang menyangkut posisi keuangan, kinerja serta perubahan posisi keuangan suatu perusahaan yang bermanfaat bagi sejumlah besar pemakai laporan keuangan dalam pengambilan keputusan secara ekonomi.

\section{d. Kinerja Keuangan}

Menurut Mulyadi (1997), Kinerja perusahaan (bank) adalah suatu tampilan perusahaan selama periode waktu tertentu, untuk mengetahui kondisi kinerjanya, maka perusahaan dapat melakukannya dengan menilai kinerja perusahaannya dan penilaian kinerja adalah penentuan secara periodik efektifitas suatu organisasi, bagan organisasi dan karyawannya berdasarkan sasaran, standar dan kriteria yang telah ditetapkan sebelumnya. Sementara menurut (Standar Akutansi Keuangan : 2001) kinerja suatu perusahaan atau bank dapat dirumuskan sebagai hasil kerja yang diperoleh atas kegiatan atau operasi yang dilakukan oleh perusahaan selama periode waktu tertentu dan laba 
merupakan salah satu tolak ukur penting dalam penilaian kinerja perusahaan atau bank.

\section{e. Rentabilitas}

Rentabilitas, menggambarkan kemampuan perusahaan mendapatkan laba melalui semua kemampuan, dan sumber daya yang ada seperti kegiatan penjualan, kas, modal, jumlah karyawan, jumlah cabang, dan sebagainya. Return On Assets adalah salah satu rasio profitabilitas. Rasio ini sering disebut sebagai rentabilitas ekonomis, yaitu merupakan ukuran kemampuan perusahaan dalam menghasilkan laba dengan semua aktiva yang dimiliki oleh perusahaan tersebut (Sutrisno, 2003:254).

Semakin tinggi nilai ROA, dapat diartikan bahwa perusahaan telah efisien dalam menciptakan laba dengan cara mengolah dan mengelola semua aset yang dimilikinya (Salim, 2010). Banyak orang menganggap bahwa return on assets sama dengan return on investment, namun sebenarnya kedua rasio tersebut berbeda, karena dalam Investment hanya ada unsur modal pinjaman jangka panjang dan ekuitas, sedangkan Assets dibiayai dari sumber pinjaman jangka panjang, ekuitas, dan utang jangka pendek (Samsul, 2006).

Sedangkan Harahap (1998) berpendapat bahwa rasio rentabilitas atau profitabilitas, menggambarkan kemampuan perusahaan mendapatkan laba melalui semua kemampuan, dan sumber daya yang ada seperti kegiatan penjualan, kas, modal, jumlah karyawan, jumlah cabang, dan sebagainya. Sementara Astuti (2004: 36) mengemukakan bahwa profitabilitas adalah kemampuan suatu perusahaan untuk menghasilkan laba dan satusatunya ukuran profitabilitas yang paling penting adalah laba bersih.

Menurut Munawir (2007) rentabilitas ekonomis dapat diukur dengan empat rasio yaitu (1) net profit margin, (2) gross profit margin, (3) return on invesment, dan (4) return on equity. Sedangkan Riyanto (2008) mengemukakan tentang pengukuran tingkat rentabilitas ekonomis terdapat lima rasio yang digunakan untuk mengukur rentabilitas ekonomis yaitu : (1) gross profit margin, (2) net profit margin, (3) basic earning power, (4) return on assets, dan (5) return on equity.

\section{METODE PENELITIAN}

\section{a. Variable Penelitian}

Menurut Arikunto (1998:91) variable penelitian yaitu obyek penelitian atau apa yang menjadi titik perhatian suatu penelitian. Dalam penelitian ini variable yang ada adalah variable independen yaitu rasio keuangan dan variable dependen yaitu Rasio Lancar 
Current Ratio, Rasio Cepat / Quick Ratio dan Quick Ratio.

b. Populasi dan Sampel

Populasi dalam penelitian ini adalah BRI Syariah yang menyajikan laporan keuangan selama tahun 2013-2015.

\section{c. Jenis dan Sumber Data}

Jenis data yang digunakan dalam penelitian ini adalah data sekunder yang sumber datanya diperoleh dari Laporan Keuangan BRI Syariah tahun 2013-2015 melalui web : www.brisyariah.co.id di akses pada tanggal 20 Januari 2017.

Gross Profit Margin

$$
=\frac{\text { Penjualan Bersih }- \text { Harga Pokok Penjualan }}{\text { Penjualan Bersih }} \times 100 \%
$$

b. Operating income ratio Operating income ratio adalah rasio ini digunakan untuk mengukur laba yang dihasilkan dengan menghubungkan kegiatan pokok perusahaan dengan asset yang dimilki perusahaan (Sawir, 2001).

Operating Income Ratio

$$
=\frac{\text { Laba Sebelum Bunga dan Pajak(EBIT) }}{\text { Penjualan Bersih }} X 100 \%
$$

c. Net Profit Margin

Net Income margin adalah

perusahaan untuk merupakan rasio yang menghasilkan pendapatan digunakan untuk bersih atau laba (Ang, 1997). mengukurkemampuan

$$
\text { Net Income Margin }=\frac{\text { Laba Setelah Bunga dan Pajak }(E A T)}{\text { Penjualan Bersih }} \times 100 \%
$$

d. Rate Return to Total Asset (ROA)

Rate return to total asset adalah rasio yang mengukur kemampuan perusahaan menghasilkan laba bersih berdasarkan tingkat aset yang tertentu (Halim, 2003). 


$$
\begin{aligned}
& \text { Rate Return to Total Asset } \\
& \qquad=\frac{\text { Laba Sebelum Bunga dan Pajak(EBIT })}{\text { Jumlah Aktiva }} \times 100 \%
\end{aligned}
$$

e. Net Earning Power Ratio (ROI)

Net earning power ratio adalah merupakan pengukuran kemampuan perusahaan secara keseluruhan di dalam menghasilkan keuntungan dengan jumlah keseluruhan aktiva yang tersedia dalam perusahaan (Syamsudin, 2004).

$$
\text { Net Earning Power Ratio }=\frac{\text { Laba Setelah Bunga dan Pajak }(E A T)}{\text { Jumlah Aktiva }} \times 100 \%
$$

\section{PEMBAHASAN}

\section{a. Kinerja Keuangan pada BRI Syariah}

Kinerja perusahaan (bank) adalah suatu tampilan perusahaan selama periode waktu tertentu, untuk mengetahui kondisi kinerjanya, maka perusahaan dapat melakukannya dengan menilai kinerja perusahaannya dan penilaian kinerja adalah penentuan secara periodik efektifitas suatu organisasi, bagan organisasi dan karyawannya berdasarkan sasaran, standar dan kriteria yang telah ditetapkan sebelumnya (Mulyadi, 1997).

Sementara menurut (Standar Akutansi Keuangan : 2001) kinerja suatu perusahaan atau bank dapat dirumuskan sebagai hasil kerja yang diperoleh atas kegiatan atau operasi yang dilakukan oleh perusahaan selama periode waktu tertentu dan laba merupakan salah satu tolak ukur penting dalam penilaian kinerja perusahaan atau bank.

\section{b. Rentabilitas pada BRI Syariah}

Rentabilitas suatu perusahaan menunjukkan kemampuan perusahaan dalam menghasilkan laba dibandingkan dengan modal yang dipergunakannya aktiva atau modal yang menghasilkan laba tersebut. Dengan kata lain rentabilitas merupakan kemampuan suatu perusahaan untuk menghasilkan laba selama periode tertentu (Riyanto, 2001; Yuliani, 2007; Mahardian,2008).

Rentabilitas perbankan menggambarkan sejauh mana keberhasilan bank itu menggunakan dana yang diinvestasikannya. Untuk mempertahankan suatu tingkat rentabilitas yang layak, bank harus memperoleh penghasilan yang dapat menutupi biaya, dan bank tersebut harus berusaha terus mempertahankan tingkat pendapatan tertentu dengan memperhitungkan faktor risiko yang dihadapi (Hermawan, 2009). Salah satu rasio rentabilitas adalah Return on Assets (ROA), yaitu rasio yang digunakan untuk mengukur kemampuan manajemen bank dalam memperoleh keuntungan secara keseluruhan. Semakin besar rasio ROA suatu bank, semakin besar pula tingkat 
keuntungan yang dicapai bank tersebut dan semakin baik pula posisi bank tersebut dari segi penggunaan assets. (Ahmadi, 2009).

Dari tabel di bawah bahwa ROA pada BRI Syariah terus mengalami penurunan sejak tahun 2013 hingga 2015 yaitu dari 1,15\%, $0,08 \%$ dan $0,76 \%$. Sedangkan ROE penurunan terjadi pada tahun 2014 sebesar $0,44 \%$ dimana sebelumnya berada pada namun $10,20 \%$ dan meningkat kembali pada tahun 2015 sebesar $6,20 \%$. Sementara net income margin juga mengalami fluktuatif. Sedangkan beban operasional juga mengalami fluktuatif dimana beban operasional tertinggi pada tahun 99,77\%, namun pada tahun 2015 berhasil ditekan.

\begin{tabular}{|l|c|c|c|}
\hline \multicolumn{1}{|c|}{ Rasio } & $\mathbf{2 0 1 3}$ & $\mathbf{2 0 1 4}$ & $\mathbf{2 0 1 5}$ \\
\hline ROA & $1,15 \%$ & $0,08 \%$ & $0.76 \%$ \\
\hline ROE & $10,20 \%$ & $0,44 \%$ & $6.20 \%$ \\
\hline Net Income Margin (NIM) & $6,27 \%$ & $6,04 \%$ & $6.66 \%$ \\
\hline Operating Expenses to Operating Revenues & $90,42 \%$ & $99,77 \%$ & $93.79 \%$ \\
\hline
\end{tabular}

\section{KESIMPULAN \\ Kesimpulan}

Berdasar analisis kinerja keuangan di atas bahwa kinerja keuangan BRI Syariah Tahun 20132015 adalah sebagai berikut :

1. Rentabilitas BRI Syariah perlu ditingkatkan dari komponenkomponen yang dapat memberi kontribusi.

2. Kinerja keuangan BRI Syariah menunjukkan kecendrungan fluktuatif, namun pada tahun 2015 BRI Syariah cenderung berhasil memperbaiki kinerja keuangannya

\section{DAFTAR PUSTAKA}

Ang, Robert. 1997. "Buku Pintar Pasar Modal Indonesia (The Intelligent Guide to Indonesian Capital Market)", Media Soft Indonesia, Jakarta.
Antonio, Muhammad Syafii (2001), Bank Syari'ah: Dari Teori ke Praktek, (Gema Insani Press bekerja sama dengan Yayasan Tazkia Cendekia)

Astuti, Dewi. 2004. Manajemen Keuangan Perusahaan, Edisi Pertama. Penerbit.Ghalia Indonesia.

Bambang Riyanto, 2001. Dasar-dasar Pembelanjaan Perusahaan, Edisi Keempat, Yogyakarta: BPFE.

Baridwan, Zaki. 2008. Intermediate Accounting. Edisi delapan. Cetakan kedua. BPFE-Yogyakarta. Dwi Prastowo dan Rifka Juliaty, 2002. Analisis Laporan Keuangan, Yogyakarta: UPP AMP YKPN, Yogyakarta.

Ghozali, Imam dan Anis Chariri, 2003. Teori Akuntansi, Semarang: Badan Penerbit Universitas Diponegoro. 
Halim, Abdul, 2007 Manajemen Keuangan Bisnis, Bogor: Ghalia Indonesia.

Harahap, Sofyan Syafri. 1998. Analisa Kritis atas Laporan Keuangan. Jakarta: PT Rajagrafindo Persada.

Hartono, Jogiyanto. 2008. Teori Portofolio dan Analisis Investasi. Edisi Kelima. Yogyakarta: BPFE.

Hermawan, Jaka. 2009. Pengaruh Rentabilitas dan Solvabilitas Terhadap Likuiditas Pada Perusahaan Perbankan Yang Go Public. Skripsi. Sumatra Utara: Universitas Sumatra Utara

Ikatan Akuntan Indonesia, 2001. Standar Akutansi Keuangan, Jakarta: Salemba Empat.

Iriyadi dan Oktafiyanthi, Arinta. 2007.

Pengakuan Pendapatan: Studi Komparasi Pada Bank

Konvensional dan Bank Syariah., Studi Kasus pada PT. Bank Jabar Bogor. vol. 7. No. 1.

Mahardian, Pandu. 2008. Analisis Pengaruh Rasio CAR, BOPO, NPL, NIM dan LDR Terhadap Kinerja Keuangan Perbankan. Tesis. Semarang: Program Pasca Sarjana Univesitas Diponegoro

Martono, dan Harjito, Agus. 2008. Manajemen Keuangan, Yogyakarta: EKONISIA.

Mulyadi, 1997. Akutansi Manajemen ( Konsep, Manfaat dan Rekayasa), Edisi Kedua, Yogyakarta: Bagian Penerbitan STIE YKPN.

Munawir S, 1999. Analisa Laporan Keuangan, Yogyakarta: Karunia Liberty.
Prasetyo Sigit, 2009. Pengaruh Loan Deposit Ratio (LDR), Capital Adequacy Ratio (CAR), Kualitas Aktifa Produktif (KAP) dan Efisiensi Operasi (BOPO) Terhadap Rentabilitas Pada BPR di Kabupaten Kudus. Skripsi. Semarang: Universitas Stikubank

Putra, Nanda Budia, (Tanpa Tahun) Analisis Kinerja Keuangan Pada Pt. Antam Tbk, Periode Tahun 2007-2011, Departemen Akuntansi, Fakultas Ekonomi Universitas Gunadarma

Riyanto, 2001, Bambang. Dasar-Dasar Pembelanjaan Perusahaan, Yogyakarta: BPFE.

Samsul, Mohamad. 2006. Pasar Modal dan Manajemen Portofolio. Jakarta: Erlangga.

Sawir, Agnes 2001. Analisis Kinerja Keuangan dan Perencanaan Keuangan Perusahaan, Penerbit BPFE, Yogyakarta.

Sutrisno. 2003. Manajemen Keuangan. Edisi Pertama. Yogyakarta: Ekonisia

Undang-Undang RI No. 21 tahun 2008 tentang Perbankan Syariah

Wild, John J., K. R. Subramanyam, dan Robert F. Halsey. 2008. Analisis Laporan Keuangan, Buku Satu, Edisi Kedelapan. Diterjemahkan oleh Yanivi S. Bachtiar dan S. Nurwahyu Harahap. Jakarta: Salemba Empat.

www.brisyariah.co.id 